\begin{tabular}{|c|c|c|}
\hline & Int.J.Curr.Microbiol.App.Sci (2021) 10(11): 259-265 & \multirow{4}{*}{ 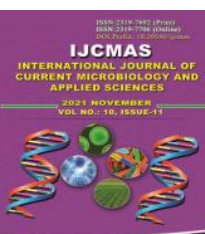 } \\
\hline & \multirow{4}{*}{$\begin{array}{l}\text { International Journal of Current Microbiology and Applied Sciences } \\
\text { ISSN: 2319-7706 Volume } 10 \text { Number } 11 \text { (2021) } \\
\text { Journal homepage: http://www.ijcmas.com }\end{array}$} & \\
\hline & & \\
\hline EXCELLENT & & \\
\hline PUBLIS & & wwW:.jicmas.com \\
\hline
\end{tabular}

\title{
Impact of Organic Seed Priming Amendments and Botanicals on Seed Quality Parameters of French Bean (Phaseolous vulgaris L.)
}

\author{
Prashant Kumar Rai ${ }^{1}$, Kotamarthi Bhavana ${ }^{1} *$ and G. M. Lal ${ }^{2}$ \\ ${ }^{1}$ Department of Genetics and Plant Breeding, Naini Agricultural Institute, Sam Higginbottom \\ University of Agriculture, Technology and Sciences, Prayagraj, 211007 U. P., India \\ ${ }^{2}$ State Institute for Management of Agriculture, Department of Agriculture, \\ Govt of. Uttar Pradesh, India \\ *Corresponding author
}

Keywords

Priming, Botanicals, French bean, Panchagavya, Tulasi leaf extract

\section{Article Info}

Received: 15 October 2021 Accepted: 02 November 2021 Available Online: 10 November 2021
The current experiment was conducted to evaluate the Performance of Organic amendments and botanical treatments on seed quality parameters of French bean under stimulated environmental conditions. An experiment was conducted in 2021 at postgraduate seed testing laboratory, Department of Genetics and Plant Breeding Naini Agriculture Institute, Sam Higginbottom University of Agriculture Technology and Sciences, Prayagraj. The French bean Cultivar Arka Bold seeds were used for priming. Organic treatments are designated as Panchagavya 2\%, 4\%,6\%,8\%, Agniasthra $2 \%, 4 \%, 6 \%, 8 \%$ and Botanicals treatments are Tulasi leaf extract 5\%, Aloevera leaf extract $5 \%$, Vinca rosea leaf extract $5 \%$ and also did hydroprming treatment using distilled water respectively. Seeds were soaked in organic, botanicals and in distilled water for duration of 6 hours followed by shade drying. The results were obtained and it was found that all the treatments showed significant effect on quality parameters. The highest was found in panchgavya of all doses followed by tulasi leaf extract found to be best in Germination percentage, Speed of Germination, Root length, Shoot length, Seedling length, Seed vigour index-I, Seed vigour Index-II compared to control or untreated seeds which indicates the effect of organics and botanicals on physiological processes of the seeds. This study revealed that priming with organic amendments and botanicals can be effective in enhancing the seed quality parameters of french bean and they are low cost, effective and nature friendly and toxic free.

\section{Introduction}

India is the largest producer of legume crop in the world. Accounts for $25 \%$ Global production, $27 \%$ of world consumption and $14 \%$ of importer. Since ages, Pulses have been well integrated into the farming system of our country as the farmer could produce them by using their own seeds and family labour without depending on much external inputs. French bean it is a major vegetable crop where indigenous pulses are also preferred (Kay 
1979 and duke 1981). According to the Food and agricultural organisation (FAO) of united nations, India is the world leader in production of dry seed of French bean as well as green beans and vegetable production. Followed by brazil and Myanmar in dry seed of French bean. On the other hand china is world leader in production of green beans followed by Indonesia and then turkey (FAOATAT, 2010).

French bean (Phaseolous vulgaris L.) commonly known as Kidney bean, Common bean, Snap bean, Navy bean, Haricot bean, Dry bean in different parts of the world. French bean is mostly grown and popular in India. It is a dipliod $(2 n=22)$ belongs to the family leguminaceae. The primary centre of origin is southern Mexico and central America. But now it is widely cultivated in India and other parts of the world.

French bean is self pollinated crop, flowers are pink, white or purple with standard and reflexed and di-adalphous stamens. It is a annual plant (Wortmann 2006).

Stem is slender and twisted. Pods are slender curved or straight, borne mostly on axillary racemes. Leaves are large without leaflets, alternate and trifoliate. Seeds are non endospermic.

Seed priming is one of the primitive techniques used to enhance early seed emergence and initiates several processes involved in the seed germination (Asegedom et al., 2001). Therefore seed priming boosts the imbibition and metabolic processes resulting in enhanced seed germination, uniform germination, seedling growth and development in both normal and stressed conditions (Ansari et al., 2012).

Seed priming is a physiological method of controlled hydration and drying to enhance sufficient pre germinative metabolic process for rapid germination and it improves the quality of the seed by enhancing the seed germination due to enzyme activation, metabolic activities, biochemical process of cell repair, protein synthesis and improvement of the antioxidant defence system compared to unprimed. Different priming techniques like Hydropriming (soaking in water), Halo priming (soaking in inorganic salt solutions), Osmo priming (soaking in osmotic solution with low water potential), Nutri priming (soaking seeds in nutrients solutions rather than pure water), Bio priming (soaking in solution containing benificial microorganisms).

Solid matrix priming (seeds are incubated to solid insoluble matrix for a given time), Phyto priming (soaking seeds in botanical or leaf extracts), Organic priming (soaking in organic solutions).

Recent studies on paddy (Shankuntala et al., 2012) found that organic priming enhances seedling vigour and enzyme activity, Panchagavaya on Okra, tomato and french bean showed miraculous result (Gayathri et al., 2015) and (Dasarathan et al., 2018) panchagvaya on okra found better germination and meristamatic growth (Kamatchi Kalal et al., and Eskaiamma et al., 2019) showed that panchagvaya priming seeds of leafy vegetables like fenugreek and amaranthus showed increased rate of germination rate, biomass and enhanced growth.

However, organic priming is more affordable so even small scale farmers can practise Keeping this into consideration need for its improvement for quality and yield. This can be achieved by maintaining the plant population by organic priming.

\section{Materials and Methods}

This experiment was conducted at the seed testing laboratory, Department of Genetics and Plant Breeding, Naini, Sam Higginbottom 
university of Agriculture, Technology and Sciences, Prayagraj, (U.P) during rabi-2021 to evaluate "Impact of organic seed priming amendments and botanicals on seed quality parameters of French bean (Phaseolous vulagaris L.).

The French bean cultivar of Arka Bold seeds were treated with organics and botanicals to evaluate the seed quality parameters.

The seeds are subjected to different soaking intensities over a period of 6 hours followed by shade drying. One hundred seeds in each replication were placed on blotter paper. Laboratory experiment using a complete randomized design with four replications. Seed quality parameters were determined according to standard procedures prescribed in roll towel method in germination cabinets with application of standard temperature T20-100 degrees centigrade for 9 days at $95 \%$ relative humidity.

Quality parameters were taken as per ISTA standards such as Germination percentage, speed of germination, root length, shoot length, seedling length, fresh weight, dry weight, seedling vigour index-I, seedling vigour index-II. The data was collected on ten randomly selected healthy seedlings from each replication and different observation were recorded.

Panchagavya was prepared from cow products viz. Cow milk(5 L), ghee (2 L), curd (2 kg), cow urine $(5 \mathrm{~L})$ and cow dung $(5 \mathrm{~kg})$; Cow curd - 2 litres Tender coconut water - 3 litres Well ripened poovan banana - 12 nos ingredients were mixed together along with $15 \mathrm{~kg}$ of jaggery in a circular container. The mixture was added with $15 \mathrm{~L}$ water and kept as such for 30 days. Fermentation took place by making the mixture to a fine concentrate giving out the sweet odour. The fermented liquid was filtered through cotton and the final volume of filtrate was made $1000 \mathrm{ml}$. The solution was stored in cool conditions.

\section{Agniasthra solution}

It is composed of 10 litre Local Cow Urine and $1 \mathrm{Kg}$ Tobacco, 500gm of Green Chilli, 500 Gram Local Garlic, $5 \mathrm{Kg}$ Need leaves pulp (crushed in urine). Grind all the ingredients into fine paste and mix with cow urine. Boil this for four times. Leave it for $48 \mathrm{hrs,} \mathrm{filter} \mathrm{it}$ and mix some water and sprinkle over the plants. You can save and use for 3 months. For the preparation of panchgaavya and agniasthra solutions for priming, Take 20 $\mathrm{ml}, 40 \mathrm{ml}, 60 \mathrm{ml}, 80 \mathrm{ml}$ of both panchagvaya and agniasthra solutions were mixed in $100 \mathrm{ml}$ of distilled water in each separate beakers to make $2 \%, 4 \%, 6 \%, 8 \%$ doses of both solutions. For the preparation of botanicals, leaf extracts of tulasi, vinca rosea, aloevera were Horticulture Research Fileds, SHUATS. These leaves were shade dried and made into fine powder. $5 \mathrm{~g}$ of each powder dissolved in $100 \mathrm{ml}$ of distilled water in 5\% solutions. Aloevera leaf extract is made by grating the aloe extract, take $5 \mathrm{~g}$ of aloevera with $100 \mathrm{ml}$ of distilled water to make the $5 \%$ sloution.

\section{Results and Discussion}

\section{Germination percentage}

Priming with panchagavya of all doses showed better germination percentage highest germination was recorded in treatment T4 (panchagavya @8\%)- $(94.000 \%)$ par with treatments T3,T2,T1 panchagavya doses (6\%.4\%,2\%) T3-panchagavya 6\% (91.000), T2-panchagavya $\quad 4 \% \quad(90.000 \%), \mathrm{T} 2 \quad-$ panchagavya 2\% (89.000\%) followed by (Tulasi leaf extract @5 \%) T9 - 87.750\% when compared with control T0 Control 77.000 which is lowest

\section{Speed of germination}

Priming with panchagavya of all doses 
showed significant effect on speed of germination and highest was recorded in treatment T4 (panchagavya @8\%)- (29.303) followed by treatments T3,T2,T1 panchagavya doses (6\%.4\%,2\%) T3-panchagavya 6\% (27.366), T2-panchagavya 4\% (26.151),T1panchagavya $2 \%$ (24.736) followed by (Tulasi leaf extract @5 \%)- T9 24.729 when compared with control T0 Control - 18.197 which is lowest.

\section{Root length}

Priming with panchagavya of all doses showed better performance on root length and Highest was recorded in treatment T4 (panchagavya @ 8\%)- (15.788cm) followed by treatments $\mathrm{T} 3, \mathrm{~T} 2, \mathrm{~T} 1$ panchagavya doses $(6 \%, 4 \%, 2 \%)$ T3- panchagavya 6\% (15.033 $\mathrm{cm}), \mathrm{T} 2$ - panchagavya $4 \%(14.060 \mathrm{~cm}), \mathrm{T} 1-$ panchagavya $2 \%(13.488 \mathrm{~cm})$ followed by Tulasi leaf extract@5\% T9 -13.140 cm when compared with control T0-10.188cm which is lowest.

\section{Shoot length}

Priming with panchagavya of all doses showed better performance on shoot length and highest was recorded in treatment T4 (panchagavya @8\%)- $15.733 \mathrm{~cm}$ followed by treatments T3,T2, T1 panchagavya doses $(6 \% .4 \%, 2 \%) \quad$ T3- panchagavya 6\% $(14.753 \mathrm{~cm}), \mathrm{T} 2-$ panchagavya $4 \%(13.853 \mathrm{~cm})$, T1 panchagavya $2 \%(13.503 \mathrm{~cm})$ followed by (Tulasi leaf extract @5 \%) T9- $13.225 \mathrm{~cm}$ when compared with control T0 Control $11.100 \mathrm{~cm}$ which is lowest.

\section{Seedling length}

Priming with panchagavya of all doses showed better performance on seedling length and highest was recorded in treatment T4 (panchagavy@8\%) -31.520cm followed by treatments T3, T2, T1 panchagavya doses $6 \%, 4 \%, 2 \%$ T3-panchagavya $6 \%(29.785 \mathrm{~cm})$, T2 - panchagavya 4\% (27.913 cm), T1 panchagavya $2 \%(26.990 \mathrm{~cm})$ Followed by (tulasi leaf extract@5\%)T9 - 26.338cm when compared with T0-22.863cm which is lowest.

\section{Fresh weight}

Priming with panchagavya of all doses showed better performance on fresh weight and highest fresh weight was recorded in treatment T4 (panchagavya@8\%) - 8.310g followed by treatments T3,T2,T1 panchagavya doses $6 \%, 4 \%, 2 \%$ T3- panchagavya $6 \%$ (8.135g), T2 - panchagavya 4\% (7.998g), T1panchagavya $2 \%$ (7.810g) Followed by (tulasi leaf extract@5\%) T9 - (7.618g) when compared with T0-5.018g which is lowest

\section{Dry weight}

Priming with panchagavya of all doses showed better performance on dry weight and highest dry weight was recorded in treatment T4 (panchagavy@8\%) - 3.033g followed by treatments T3, T2,T1 panchagavya doses 6\%,4\%,2\% T3-panchagavya 6\% (2.920g), T2panchagavya $4 \%$ (2.833g), T1- panchagavya $2(2.775 \mathrm{~g})$ followed by (tulasi leaf extract@5\%)T9 -(2.703g) when compared with T0-2.205g which is lowest

\section{Seedling Vigour Index -I}

Priming with panchagavya of all doses showed better performance on seedling vigour index-I and highest was recorded in treatment T4 (panchagavy@8\%) -(2,962.100) followed by treatments T3, T2,T1 panchagavya doses $6 \%, 4 \%, 2 \%$ T3-panchagavya $6 \%(2,708.475)$, T2-panchagavya $\quad 4 \% \quad(2,512.315), \mathrm{T} 1-$ panchagavya $(2,402.045)$ followed by (tulasi leaf extract@5\%) T9 - $(2,310.730) \quad$ when compared with T0-1,760.720 which is lowest. 
Table.1 Mean Performance of seed quality parameters due to various priming treatments in French bean

\begin{tabular}{|c|c|c|c|c|c|c|c|c|c|c|}
\hline S.no & Treatments & $\begin{array}{c}\text { Germination } \\
\text { Percentage }\end{array}$ & $\begin{array}{c}\text { Speed of } \\
\text { germination }\end{array}$ & $\begin{array}{r}\text { Root } \\
\text { length }\end{array}$ & $\begin{array}{l}\text { Shoot } \\
\text { length }\end{array}$ & $\begin{array}{l}\text { Seedling } \\
\text { length }\end{array}$ & $\begin{array}{c}\text { Seedling } \\
\text { fresh } \\
\text { weight }\end{array}$ & $\begin{array}{c}\text { Seedling } \\
\text { dry } \\
\text { weight }\end{array}$ & $\begin{array}{c}\text { Seedling } \\
\text { Vigour } \\
\text { Index-I }\end{array}$ & $\begin{array}{l}\text { Seedling } \\
\text { Vigour } \\
\text { Index-II }\end{array}$ \\
\hline 1 & T0 & 77.000 & 18.197 & 10.188 & 11.100 & 22.863 & 5.018 & 2.205 & $1,760.720$ & 163.418 \\
\hline 2 & $\mathrm{~T} 1$ & 89.000 & 24.736 & 13.488 & 13.503 & 26.990 & 7.810 & 2.775 & $2,402.045$ & 244.290 \\
\hline 3 & $\mathrm{~T} 2$ & 90.000 & 26.151 & 14.060 & 13.853 & 27.913 & 7.998 & 2.833 & $2,512.315$ & 253.610 \\
\hline 4 & $\mathrm{~T} 3$ & 91.000 & 27.366 & 15.033 & 14.753 & 29.785 & 8.135 & 2.920 & $2,708.475$ & 265.705 \\
\hline 5 & $\mathrm{~T} 4$ & 94.000 & 29.303 & 15.788 & 15.733 & 31.520 & 8.310 & 3.033 & $2,962.100$ & 284.985 \\
\hline 6 & T5 & 85.000 & 23.852 & 11.375 & 12.103 & 24.103 & 6.115 & 2.340 & $2,049.080$ & 198.915 \\
\hline 7 & T6 & 86.000 & 24.022 & 11.795 & 12.373 & 24.540 & 6.480 & 2.425 & $2,111.005$ & 208.565 \\
\hline 8 & $\mathrm{~T} 7$ & 86.500 & 24.214 & 12.115 & 12.748 & 25.118 & 6.845 & 2.503 & $2,173.775$ & 216.480 \\
\hline 9 & $\mathrm{~T} 8$ & 86.500 & 23.628 & 12.605 & 12.955 & 25.403 & 7.075 & 2.570 & $2,197.645$ & 222.280 \\
\hline 10 & T9 & 87.750 & 24.729 & 13.140 & 13.225 & 26.338 & 7.618 & 2.703 & $2,310.730$ & 239.175 \\
\hline 11 & T10 & 84.000 & 23.778 & 10.825 & 11.823 & 23.813 & 5.890 & 2.253 & $2,000.270$ & 189.185 \\
\hline 12 & $\mathrm{~T} 11$ & 82.000 & 21.741 & 10.420 & 11.510 & 23.305 & 5.498 & 2.228 & $1,910.905$ & 180.510 \\
\hline 13 & T12 & 87.500 & 24.407 & 12.635 & 12.900 & 25.535 & 7.338 & 2.633 & $2,234.620$ & 230.380 \\
\hline \multicolumn{2}{|c|}{ Grand mean } & 79.98 & 24.31 & 12.574 & 12.967 & 25.940 & 6.933 & 2.570 & 2256.437 & 222.884 \\
\hline \multicolumn{2}{|r|}{ C.D } & 3.281 & 1.853 & 0.606 & 0.631 & 1.101 & 0.340 & 0.054 & 127.222 & 10.102 \\
\hline \multicolumn{2}{|r|}{ SE(m) } & 1.143 & 0.645 & 0.211 & 0.220 & 0.383 & 0.119 & 0.019 & 44.308 & 3.518 \\
\hline \multicolumn{2}{|r|}{ SE(d) } & 1.616 & 0.913 & 0.298 & 0.311 & 0.542 & 0.168 & 0.026 & 62.661 & 4.975 \\
\hline \multicolumn{2}{|r|}{ CV } & 2.638 & 5.308 & 3.356 & 3.390 & 2.957 & 3.419 & 1.453 & 3.927 & 3.157 \\
\hline
\end{tabular}




\section{Seedling Vigour Index-II}

Priming with panchagavya of all doses showed better performance on seedling vigour index-II and highest was recorded in treatment T4 (panchagavya @ 8\%) - (284.985) followed by treatments T3, T2, T1 panchagavya doses $6 \%, 4 \%, 2 \%$ T3-panchagavya $6 \%$ (265.705), T2-panchagavya $4 \% \quad$ (253.610), T1panchagavya (244.290) Followed by (tulasi leaf extract@5\%)T9 - (239.175) when compared with T0- 163.418 which is lowest.

Microbes and growth promoters in panchagavya promoter's germination ability. In the present study also the presence of certain growth hormones interfere with germination ability. Panchagavya has been reported to contain micronutrients, macronutrients, many vitamins, essential amino acids, growth promoting factors and beneficial microbes. The higher root and shoot length may be due to the presence of easily available organic $\mathrm{C}, \mathrm{N}, \mathrm{P}, \mathrm{K}$. This availability is very much required for plant nutrition. Increase in the fresh weight and dry weight of different plant parts due to improved mobilization of nutrients. Rapid germination of seeds due to priming ultimately could lead to the production of larger seedlings. The results presented confirm that primed seed exhibit early vigour and produce significantly taller root and shoot and thereby heavier seedlings due to enhanced activity of alphaamylase.

Similar results were observed and confirmed by Gayathri et al., (2015), Saritha et al., (2013), Pavan shinde et al., (2019) and Kamatchi kalal et al., and R. Esakiamma et al., (2019).

From the present investigation it is concluded that pre soaking treatments with organic amendments and botanicals can be used for the enhancement of germination and vigour of the French bean. Organic priming with panchagavya of all treatment T4@8\%,T3@6\%,T2@4\%,T1@2\% doses found to be best among all the treatments followed by $\mathrm{T} 9$ treatment -tulasi leaf extract @5\% and T0- control being the lowest. The experimental observations of increase in percentage of panchagavya dosage showed increase in germination and quality parameters which indicates the effect of organics and botanicals on physiological processes of the seeds. However percentage of doses varied for crop to crop. Organic amendments and Botanicals being cheap, nature friendly and easily available to farmers can be efficiently used for improving seed quality parameters.

\section{Future scope}

Further experiment need to be done on field condition for more better result and findings.

\section{Acknowledgement}

The author are thankful to the Honourable vice chancellor, Head of the department, Advisor, Teaching and non teaching staff of Department of Genetics and Plant Breeding, Sam Higginbottom University of Agriculture, Technology And Sciences, Prayagraj, U.P. for providing all necessary facilities and support.

\section{References}

Amalraj March(2013). Microbiological analysis of Panchagavya, vermicompost, and FYM and their effect on plant growth promotion of pigeon pea (Cajanus cajan L.) in India, Organic Agriculture $3(1)$

DOI:10.1007/s13165-013-0042-2.

Dezfuli, Pegah Moradi and Sharif-zadeh, Farzad and Janmohammadi, Mohsen (2008). Influence of priming techniques on seed germination behaviour of maize inbred lines (Zea 
mays L.). ARPN Journal of Agricultural and Biological Science, 3 (3). pp. 22-25.

Dhasarathan, S. Charumathi, R. Nagavasuda, K. Cholapandian, A. J. A Ranjit singh(2018). Plant growth promotion using Panchagavya, International journal of research and review, Vol.5, Issue, 10, pp194-195, 2018.

Farooq, M., Usman, M., Nadeem, F., Hafeez ur Rehman., Abdul Wahid., Basra, S. M. A., \& Siddique, K. H. M. (2019). Seed priming in field crops: potential benefits, adoption and challenges. Crop and Pasture Science, 70 (9), 731771.

Food and Agriculture Organization, (2017). WWW.FAO.Org., Area, production and productivity of pulses.

Gayathri V, Nesiriya M, Karthika M, Jisha Sebastian.(2015).Study on growth of vegetable crops using panchagavya. Int. J Current research. 2015; 7(10):21093-21096.

ISTA. International rules for seed testing, rules 1996. Seed Science and Technology, 24 (supplement), 1996.

Kamatchi Kala1. B and R. Esakiammal Alias Eswari(2019. Effect of Panchagavya on Seed Germination, Seedling Growth and Nutrient Content of Some Leafy Vegetables. International Journal of Scientific Research in Research Paper. Biological Sciences Vol.6, Issue.6, pp.56-60, December (2019) E-ISSN: 2347-7

Saritha, M. and Vijayakumari, (2013). Influence of Selected Organic Manures on the Seed Germination and Seedling Growth of Cluster Bean. Journal of Wollega University, Ethiopia, Page: 2226-7522.

Shakuntala. N. M., Vasudevan. S. N., Patil, S. B., Doddagoudar R., Mathad C., Macha. I and Vijaykumar A. G. (2012). Organic biopriming on seed vigour inducing enzyme in paddy - an alternative to inorganics. The Ecosan. Special issue, Vol. 1: $251-257$

Somasundharam, E.; Mohamed, M.; Manullah, A.; Thirukkumaran, K.; Chandrasekaran, R.; Vaiyapuri, K. and Sathyamoorthi, K. (2007). Biochemical changes, Nitrogen flux and yield of crops due to organic sources of nutrients under maize based cropping system. J.Appl. Sci. Res., 3(12): 1724-1729.

\section{How to cite this article:}

Prashant Kumar Rai, Kotamarthi Bhavana and Lal, G. M. 2021. Impact of Organic Seed Priming Amendments and Botanicals on Seed Quality Parameters of French Bean (Phaseolous vulgaris L.). Int.J.Curr.Microbiol.App.Sci. 10(11): 259-265.

doi: https://doi.org/10.20546/ijcmas.2021.1011.030 